\title{
PENGARUH PENGGUNAAN BAHAN PENGASAP TONGKOL JANGUNG DAN SABUT KELAPA TERHADAP NILAI SENSORI DAN KIMIA IKAN TEMBANG (Sardinella Fimbriata) ASAP
}

The Effect on The Use of Corn Cob and Coconut Fiber Against The Sensory and Chemical Values of Smoke Sardinella (Sardinella fimbriata)

\author{
Arsad*, Moh. Nuh Ibrahim, Haslianti \\ Jurusan Teknologi Hasil Perikanan, Fakultas Perikanan dan Ilmu Kelautan Universitas Halu Oleo, Kendari, \\ Sulawesi Tenggara, Indonesia \\ *Email korespondensi: thparsad@gmail.com (Telp: +6282393682328) \\ Diterima: 27 Desember 2020/ Disetujui 18 Maret 2021
}

Cara sitasi: Arsad, Ibrahim MN, Haslianti. 2021. Pengaruh penggunaan bahan pengasap tongkol jangung dan sabut kelapa terhadap nilai sensori dan kimia ikan tembang (Sardinella fimbriata) asap. Jurnal Fish Protech. 4(1):62-71.

\begin{abstract}
This study aims to determine the influence of the use of coconut fiber smoke and corn cob against the smoke - high fish and the chemical content of smoked fish. This research uses the group Random Plan (RAK) consisting of three treatments, namely (P1) Coconut husks $3 \mathrm{Kg}$, (P2) Corn Cob $3 \mathrm{KG}$, (P3) coconut husks and Corn cob $3 \mathrm{Kg}$. Analysis of sensory tests and chemical content (AOAC method). The highest sensory test value, (color) P3 6.76, (Bau) P3 6.38, (flavor) P1 7.05 and (texture) P3 6.14. The highest value of chemical content, moisture content in Treatment (P3) with a value of $10.06 \%$, ash content (P3) with a value of $8.48 \%$, protein level with value, (P1) $46.64 \%$ and fat with a value (P2) 16.02. From the real Difference test statistics (DMRT) shows that there are very real influences on, Aroma, ash content and fat content.
\end{abstract}

Keywords: Sardinella fimbriata, smoke, sensory test, chemical content.

\section{ABSTRAK}

Penelitian ini bertujuan untuk Mengetahui pengaruh pengunaan bahan pengasap sabut kelapa dan tongkol jagung terhadap ikan tembang asap nilai sensori dan kandungan kimia ikan tembang asap. Penelitian ini menggunakan Rancangan Acak Kelompok (RAK) yang terdiri tiga perlakuan yaitu (P1) Sabut Kelapa 3 Kg, (P2) Tongkol Jagung 3 Kg, (P3) Sabut Kelapa dan Tongkol Jagung $3 \mathrm{Kg}$. Analisis uji Sensori dan kandungan kimia (metode AOAC). Nilai uji Sensori tertinggi, (Warna) P3 6,76, (Bau) P3 6,38, (Rasa) P1 7,05 dan (Tekstur) P3 6,14. Nilai kandungan kimia tertinggi, kadar air pada perlakuan (P3) dengan nilai 10,06\%, kadar abu (P3) dengan nilai 8,48\%, kadar protein dengan nilai, (P1) 46,64\% dan Lemak dengan nilai (P2) 16,02. Dari statistik uji beda nyata (DMRT) menunjukan bahwa terdapat pengaruh sangat nyata pada, Aroma, Kadar Abu dan Kadar Lemak.

Kata kunci: Sardinella fimbriata, asap, uji sensori, kandungan kimia

\section{PENDAHULUAN}

Ikan tembang (sardinella fimbriata) merupakan kelompok ikan pelagis kecil yang memiliki nilai ekonomis penting di indonesia karena sejumlah kandungan gizi. Data produksi ikan tembang di Indonesia tahun 2018-2019 sebesar 361.844 ton dan perkirakan terus meningkat (KKP 2019). Tingginya jumlah produksi tersebut perlu dilakukan upaya pengolahan, sehingga menjadi sumber protein bagi masyarakat.

Indonesia sebagai negara agraris, mempunyai sumber energi biomassa yang melimpah. Salah satu sumber energi biomassa di Indonesia yang potensial adalah tongkol jagung. Menurut Data Kementerian Pertanian (2007), produksi jagung rata-rata 
diperkirakan sebanyak 12.193.101 ton per tahun. Dari produksi jagung tersebut diperkirakan akan menghasilkan limbah sebanyak 8.128.734 ton tongkol jagung per tahun.

Tongkol jagung merupakan salah satu limbah jagung yang tidak terpakai lagi, tongkol jagung mengandung kadar unsur karbon $43,42 \%$ dan hidrogen $6,32 \%$ dengan nilai kalornya berkisar antara 14,7 18,9 MJ/kg. selama ini masyarakat cenderung memanfaatkan limbah tongkol jagung hanya sebagai bahan pakan ternak,bahan bakar atau terbuang percuma.untuk menghindari hal ini perlu adanya pemanfaatan limbah tongkol jagung tersebut, salah satunya yaitu sebagai bahan baku arang aktif (Mutmainnah, 2012).

Pemanfaatan tongkol jagung masih sangat terbatas. Kebanyakan limbah tongol jagung hanya digunakan untuk bahan tambahan makanan ternak, atau hanya digunakan sebagai bahan bakar setelah melalui proses pengeringan. Lumempouw et al. (2012), dalam penelitian yang dilakukan menunjukkan bahwa eksrak tongkol jagung memiliki kandungan fenolik yang sejalan dengan nilai SPF selain itu Saleh et al. (2012), mengungkapkan bahwa senyawa aktif yang terkandung dalam ekstrak tongkol jagung memiliki kemapmpuan yang baik dalam menangkal radikal bebas yang bekerja menghambat oksidasi dengan cara bereaksi dengan radikal bebas aktif rekatif membentuk radikal bebas takreaktif yang relative stabil sehingga memungkinkan bermanfaat dalam memperlambat proses fotooksidasi akibat paparan sinar matahari.

Sabut kelapa adalah salah satu biomassa yang mudah didapatkan dan merupakan hasil samping pertanian, penggunaan bahan pengasap sabut kelapa dan tempurung kelapa dapat dimanfaatkan dengan baik. Komposisi sabut dalam buah kelapa sekitar 35\% dari berat keseluruhan buah kelapa. Sabut kelapa terdiri dari serat (fiber) dan gabus (pitch) yang menghubungkan satu serat dengan serat yang lainnya. Sabut kelapa terdiri dari $75 \%$ serat dan $25 \%$ gabus (Pino et al., 2005).

Senyawa fenol yang terdapat dalam asap sabut kelapa mampu mempertahankan lemak dari kerusakan. Hal ini juga sejalan dengan penelitian Djaafar (2007). menyatakan bahwa penambahan asap cair sebagai senyawa yang berperan sebagai antioksidan.

Pengasapan ikan merupakan pemanfaatan dengan cara mengolah bahan baku ikan segar menjadi output ikan asap dengan tujuan melindungi ikan segar dari pembusukan dan kerusakan. Menurut Moeljanto (1992), hasil perikanan merupakan komoditi yang cepat mengalami kemunduran mutu, atau mengalami pembusukan, karena ikan mempunyai kandungan protein (18-30\%) dan air yang cukup tinggi $(70-80 \%)$ sehingga merupakan media yang baik bagi perkembangan bakteri pembusuk. Pengasapan ikan ini lebih dipilih pelaku usaha pengolahan ikan karena pengasapan ikan adalah pengolahan yang dapat dilakukan dengan sederhana menggunakan alat dan bahan yang tradisonal sehingga bergantung pada biaya yang murah dan mudah dikerjakannamun menghasilkan output yang memiliki rasa dan aroma.

Ikan tembang merupakan sumberdaya ikan pelagis kecil dan salah satu sumberdaya perikanan yang melimpah di perairan Indonesia, termasuk di selat sunda, Banten.ikan tembang ini sangat digemari masyarakat untuk dikonsumsi dengan nilai jual yang relatif terjangkau bagi semua kalangan ekonomi masyarakat. selain dalam pemenuhan gizi, ikan tembang juga berperan dalam peningkatan lapangan kerja masyarakat sekitar melalui jasa pengolahan maupun perdagangannya. Seiring dengan meningkatnya jumlah penduduk di dunia dan kebutuhan akan bahan pangan dan gizi yang lebih baik, maka permintaan akan ikan terus meningkat dari tahunke tahun termasuk ikan tembang (Widodo dan Suadi, 2006).

Pemanfaatkan ikan tembang hasil tangkap yang berlimpah dan meningkatkan nilai ekonomisnya, Pengolahan ikan tembang asap bisa mempertahankan kualitas dan daya simpan, pengasapan pengabungan dari proses pengaraman dan pengerimgan dan pemberian asap untuk mencegah kerusakan, kerusakan dan memerlukan penanganan dan memanfaatkan hasil tangkap yang berlimpah. Ikan Tembang Menurut Nontji (1993), masih semarga 
dengan ikan lemuru yang sering ditangkap di perairanperairan pantai. Ikan ini dalam bahasa Inggris lebih dikenal dengan nama Sardine. Menurut Dwiponggo (1982), tanda-tanda umum dari ikan tembang adalah warna biru kehijauan pada punggung atau badan bagian atas, warna puth keperakan pada bagian bawah, sirip pucat kehijauan tembus cahaya, bentuk badan memanjang gepeng, sisi perut bulat agak menipis, juga pada sisi punggung. komposisi kima ikan tembang adalah sebagai berikut : air $79,6 \%$, protein 16,6\% dan lemak 2,0\% Suratinojo, (1988). Penanganan dengan metode pengasapan saat ini banyak sekali dilakukan, bahan baku asap yang digunakan sangat mempengaruhi aroma dan kandungan pada produk ikan asap. Bahan pengasap yang digunakan dalam proses pengasapan ikan (hot smoking) pada penelitian ini yaitu tempurung kelapa dan sabut kelapa.

\section{METODE PENELITIAN}

\section{Bahan}

Bahan yang digunakan dalam penelitian ini yaitu ikan tembang yang diperoleh dari penjual ikan di Pasar Pelelangan TPI Kota Kendari Sulawesi Tenggara. dan bahna pengasap yang digunakan meliputi sabut kelapa sebanyak $13,5 \mathrm{~kg}$ dan tongkol jagung sebanyak $13,5 \mathrm{~kg}$. garam dan air.semuanya sebanyak $27 \mathrm{~kg}$ bahan pengasap. Pengambilan sabut kelapa ini diperoleh dari Kelurahan Lansilowo Kecamatan Wawonii Utara Konawe Kepulauan sedangkan tongkol jagung diperoleh dari desa Amesiu Kecamatan Pondidaha Kabupaten Konawe.

\section{Pembuatan Ikan Tembang Asap.}

\section{Penyediaan Bahan Baku}

Bahan yang digunakan dalam pengasapan ini adalah ikan tembang yang diperoleh dari penjual ikan di Pasar Pelelangan TPI Kota Kendari Sulawesi Tenggara. Bahan pengasap yang digunakan meliputi sabut kelapa sebanyak $13,5 \mathrm{~kg}$ dan tongkol jagung sebanyak $13,5 \mathrm{~kg}$. dan semuanya sebanyak $27 \mathrm{~kg}$ bahan pengasap. Pengambilan sabut kelapa ini diperoleh dari Kelurahan Lansilowo Kecamatan Wawonii Utara Konawe Kepulauan sedangkan tongkol jagung diperoleh dari desa Amesiu Kecamatan Pondidaha Kabupaten Konawe. Pencucian Ikan tembang dicuci dengan air bersih ikan yang akan diasapi terlebih dahulu,disusun mengunakan bambu kecil yang telah disediakan dan kemudian dibersihkan kembali setelah selesai di susun di cuci kembali dengan air bersih.

\section{Penggaraman}

Ikan yang sudah bersih atau sudah mengalami perlakuan pendahuluan sudah dicuci dengan air bersih dilakukan proses penggaraman. Ikan direndam dengan larutan garam sebanyak $2 \%$ selama 5 menit. Penggaraman ini menyebabkan terjadinya penarikan air dan penggumpalan protein dalam daging ikan sehingga mengakibatkan tekstur ikan menjadi lebih kompak

\section{Disusun Mengunakan Bambu Runcing Kecil}

Setelah dan pencucian dengan air tawar, selanjutnya dilakukan penyusunan ikan tembang dengan mengunakan bambu runcing kecil, kemudian diangin-anginkan selama 5 menit diruang terbuka. Tujuannya yaitu untuk menghilangkan sebagian air sebelum proses pengasapan. Proses pengeringan ini sangat menentukan kekompakan atau kekenyalan produk asap.

\section{Pengasapan lkan}

Pada tahap ini, diawali dengan menyiapkan ikan yang sudah melalui proses pencucian ikan, penggaraman dan disusun mengunakan bambu runcing kecil. Setelah itu mempersiapkan bahan pengasap dengan cara menimbang masing-masing bahan pengasap. Pertama-tama menimbang bahan pengasap tongkol jagung sebagai perlakuan pertama sebanyak $3 \mathrm{~kg}$. Kemudian menimbang bahan pengasap sabut kelapa sebanyak $3 \mathrm{~kg}$ sebagai perlakuan ke dua dan menimbang tongkol jagung dan sabut kelapa sebanyak $3 \mathrm{~kg}$ (tongkol jagung $1,5 \mathrm{~kg}$ dan sabut kelapa $1,5 \mathrm{~kg}$ ) sebagai perlakuan ke tiga. Setelah masing-masing bahan pengasap telah melalui proses penimbangan, bahan pengasap tongkol jagung

http://ojs.uho.ac.id/index.php/jfp 
sebagai perlakuan pertama dimasukkan pada tungku dan dibakar hingga menghasilkan asap. Proses ini berlaku untuk perlakuan ke dua dan ke tiga. Masingmasing perlakuan dengan 3 kali pengulangan sehingga terdapat 9 percobaan. Setelah itu ikan segera dimasukkan ke dalam alat pengasapan yang telah disiapkan dalam bentuk utuh dengan posisi tergantung selama 3 jam dengan suhu $60^{\circ} \mathrm{C}-80^{\circ} \mathrm{C}$ hingga menghasilkan ikan tembang asap. Hasil pengasapan ditandai dengan bau harum yang khas dari ikan asap. Alat yang digunakan untuk mengukur suhu pada proses pengasapan ini adalah thermo meter.

\section{Penilaian Organoleptik}

Penilaian organoleptik terhadap produk ikan tembang yang meliputi warna, aroma, rasa, dan tekstur dengan menggunakan format pengujian sensori.Pengujian ini menggunakan 20 orang panelis. Uji Kimia Ikan Tembang
Analisis uji kimia ikan tembang meliputi analisis kadar air, analisis kadar abu, analisis kadar protein, analisis kadar karbohidrat dan analisis kadar serat (AOAC, 2005).

\section{Rancangan Penelitian}

Penelitian ini menggunakan Rancangan Acak Kelompok (RAK) yang terdiri dari tiga perlakuan bahan pengasap yaitu P1 (Sabut Kelapa), P2 ( Tongkol Jagung), P3 (Sabut Kelapa dan Tongkol Jagung ). Masing-masing perlakuan dilakukan tiga kali ulangan, sehingga diperoleh jumlah satuan percobaan sebanyak 9 unit.

\section{Analisis Data}

Data dianalisis dengan menggunakan sidik ragam Analysis of Variance (ANOVA), jika terdapat pengaruh nyata terhadap variabel pengamatan, maka dilanjutkan dengan uji Duncan's Multiple Range Test (DMRT) pada taraf kepercayaan 95\% $(\alpha=0,05)$.

\section{HASIL DAN PEMBAHASAN}

Hasil analisis sidik ragam produk ikan tembang asap terhadap penilaian uji sensori yang meliputi warna, aroma, rasa, dan tekstur disajikan pada Tabel 1.

Tabel 1.Hasil analisis ragam dari uji sensori dan uji kimia tembang asap.

\begin{tabular}{llll}
\hline Parameter & \multicolumn{3}{l}{ Perlakuan } \\
\cline { 2 - 3 } & P1 & P2 \\
\hline Nilai Organoleptik & & & \\
Warna & $6,38 \pm 0,4$ & $6,2 \pm 0,21$ & $6,76 \pm 0,28$ \\
Aroma & $5,82^{\mathrm{a}} \pm 0,39$ & $6,14^{\mathrm{b}} \pm 0,32$ & $6,38^{\mathrm{b}} \pm 0,25$ \\
Rasa & $7,05 \pm 0,21$ & $6,73 \pm 0,28$ & $6,84 \pm 0,53$ \\
Tekstur & $5,96 \pm 0,5$ & $6,09 \pm 0,5$ & $46,14 \pm 0,36$ \\
\hline Nilai Kimia & & & \\
Kadar Air & $10,31 \pm 0,26$ & $10,41 \pm 0,12$ & $10,06 \pm 0,13$ \\
Kadar Abu & $8,44 \pm 0,17$ & $7,31 \pm 0,13$ & $8,48 \pm 0,32$ \\
Kadar Protein & $46,64 \pm 0,53$ & $44,92 \pm 0,26$ & $45,89 \pm 0,52$ \\
Kadar lemak & $9,97 \mathrm{a} \pm 0,42$ & $16,02^{\mathrm{b}} \pm 0,26$ & $15,49 \mathrm{~b} \pm 0,25$ \\
\hline
\end{tabular}

Berdasarkan data pada Tabel 1 menunjukkan bahwa pada ikan tembang asap dengan pengunaan bahan pengasap sabut kelapa dan tongkol jagung meliputi warna,rasa dan tekstur tidak berpengaruh nyata, sedangkan aroma berpengaruh nyata terhadap uji sensori, dan sedangkan kadar air ,kadar protein, tidak berpengaruh nyata, sedangkan kadar abu dan kadar lemak berpengaruh sangat nyata terhadap uji kimia. 


\section{Sifat Organoleptik}

\section{Warna}

Hasil penilaian uji sensori atribut warna menunjukan bahwa perlakuan gabungan antara bahan pengasap sabut kelapa dan tongkol jagung (P3) memperoleh nilai tertinggi 6,76 yaitu merah keemasan dan mengkilat, sedangkan nilai terendah diperoleh pada perlakuan dengan penambahan bahan pengasap tongkol jagung (P2) diperoleh nilai 6,2 yaitu coklat mengkilat. Diduga dikarnakan kadar komponen penyusun tongkol jagung . Senyawa Selulosa hemiselulosa ataupun ligin kan memberi warna spesifik dan dapat menarik perhatian panelis. Hal ini disebabkan karena pengaruh bahan pengasap sehingga terjadi perubahan warna. Asap yang dihasilkan tongkol jagung memberikan perbedaan, dimana semakin banyak asap yang dihasilkan maka warna yang dihasilkan berbeda. Menurut Afrianto dan Liviawati (1989), zat-zat kimia yang dihasilkan dari pembakaran bahan bakar dalam proses pengasapan dapat memberikan warna merah keemasan dan dapat memberikan daya tarik pada konsumen. Lebih lanjut dikatakan (Moeljanto, 1992) menyatakan bahwa warna yang dikehendaki oleh konsumen sebagai warna ideal dari ikan hasil proses pengasapan adalah warna kuning emas kecoklatan.

\section{Aroma}

Hasil penilaian uji sensori atribut aroma menunjukan bahwa perlakuan gabungan antara bahan pengasap sabut kelapa dan tongkol jagung (P3) diperoleh nilai 6,38 aroma asap yang dihasilkan tembang sangat tajam dan harum khas tembang asap, sedangkan nilai terendah dihasilkan pada penggunaan bahan pengasap sabut kelapa (P1) memiliki nilai 5,82 aroma asap yang dihasilkan harum sedikit tercium aroma khas tembang asap. Diduga karena kadar lignin pada sabut kelapa dan tongkol jagung berbeda, yang bila dibakar secara bersamaan, maka masing-masing komponen tersebut akan menghasilkan senyawa volatil aromatik dalam asap yang akan bereaksi dengan protein pada ikan, sehingga akan menghasilkan aroma ikan yang spesifik. Jónsdóttir et al. (2008) senyawa fenolik seperti guaiakol dan siringol merupakan senyawa yang sangat khas menghasilkan aroma ikan asap. Huda et al. (2010) melaporkan bahwa selama proses pengasapan, lignin pada kayu yang tersusun atas guaiakilpropana dan siringil propane, ketika dipirolisis menghasilkan campuran senyawa fenol yang kompleks, polisiklik aromatik hidrokarbon dan senyawa karbonil.

\section{Rasa}

Hasil penilaian uji sensori atribut rasa pada Tabel 5. Hasil uji menunjukkan bahwa pada perlakuan (P1) bahan pengasap sabut kelapa dengan nilai tertinggi 7,05 dan nilai terendah pada perlakuan penggunaan sabut kelapa dan tongkol jagung (P2) dengan nilai 6,73. Hal Diduga karena pengaruh pembakaran bahan pengasap yang bersamaan. kompenen kandungan fenol yang terdapat dalam sabut kelapa memberi nilai tertinggi. bahan pengasap sabut kelapa dan tongkol jagug, rasa yang disukai oleh panelis yaitu ikan tembang yang diasap menggunakan bahan pengasap sabut kelapa. Hal ini diduga karena kadar lignin pada sabut kelapa dan tongkol jagung berbeda, yang bila dibakar secara bersamaan, maka masing-masing komponen tersebut akan menghasilkan senyawa volatil aromatik dalam asap yang akan berekasi dengan protein pada ikan, sehingga akan menghasilkan rasa ikan yang spesifik. Berdasarkan hasil nilai rata-rata Rasa tembang asap dengan penpengaruh penggunaan bahan pengasap sabut kelapa dan tongkol jagung menunjukan nilai tertinggi pada perlakuan penggunaan bahan pengasap sabut kelapa (P1) dengan nilai 7,05 dan nilai terendah pada perlakuan penggunaan bahan pengasap tongkol jagung (P2) dengan nilai 6,73. Lempang et al. (2011) melaporkan bahwa kadar lignin sabut kelapa sebesar 26,70\%. Huda et al. (2010) melaporkan bahwa selama proses pengasapan, lignin pada kayu yang tersusun atas guaiakol propana dan siringil propane, ketika dipirolisis menghasilkan campuran senyawa fenol yang kompleks, polisiklik aromatik hidrokarbon dan senyawa karbonil. Martinez et al. (2007), Giullén dan Errecalde (2002) dan Cardinal et al. (2006) menyatakan bahwa senyawa fenolik dan karbonil yang terserap ke dalam daging ikan, serta adanya senyawa volatil yang beragam, 
secara langsung mempengaruhi rasa produk ikan asap.

\section{Tekstur}

Hasil penilaian uji sensori atribut tekstur pada

Tabel 6 perlakuan penggunaan bahan pengasap gabungan antara sabut kelapa dan tongkol jagung (P3) diperoleh nilai tertinggi 6,14 tekstur alot Diduga dikarnakan dibakar bahan pengasap bersamaan dan kadar komponen penyusun tongkol jagung dan sabut kelapa. Senyawa Selulosa hemiselulosa ataupun ligin kan memberi tekstur spesifik dan dapat menarik perhatian panelis. dan lembut dan nilai terendah terdapat pada perlakuan penggunaan bahan pengasap tongkol jagung P1 diperoleh nilai 5,96 yaitu agak lembut. Penggunaan campuran sabut kelapa dan tongkol jagung (P3) sebagai bahan pengasap memberikan nilai yang paling tinggi sementara penggunaan bahan pengasap (P1) memberikan nilai tekstur yang paling rendah, dimana pada penelitian ini semakin tinggi nilai tekstur semakin lembut dan alot daging tembang asap dan semakin rendah nilai tekstur akan menghasilkan agak lembut pada daging tembang asap.

\section{Sifat Kimia}

\section{Kadar Air}

Hasil analisis uji proksimat tembang asap diperoleh nilai kadar air ikan tembang asap diperoleh nilai tertinggi yaitu pada perlakuan penggunaan bahan pengasap tongkal jagung (P2) dengan nilai 10,41\% dan nilai terendah yaitu pada perlakuan gabungan antara pengasap tongkol jagung dan sabut kelapa (P3) dengan nilai 10,06\%. Tingginya kadar air sampel penambahan bahan pengasap tongkol jagung (P2) diduga dikarnakan banyaknya asap yang dihasilkan dan kandungan senyawa yang terdapat pada bahan pengasap tongkol jagung. kadar senyawa kompleks lignin dalam tongkol jagung adalah 6,7-13,9\%, untuk hemiselulose $39,8 \%$, dan selulose $32,3-45,6 \%$. Selulose hampir tidak pernah ditemui dalam keadaan murni, melainkan selalu berikatan dengan bahan lain yaitu lignin dan hemiselulose. ( Rasyid, 2013). perbedaan senyawa bahan pengasap berbeda, sedangkan kadar senyawa yang terdapat pada sabut kelapa mengandung lignin $(35 \%$ - 45\%) dan selulosa
(23\%-43\%). (Palungkun, 1992). akibat berbeda kadar komponen hemiselulosa, selulosa dan ligin bahan pengasap yang berbeda yang tidak sama sehingga diduga menghasilkan panas yang berbeda. Sigurgiladottir (2010) menyatakan bahwa perbedaan nilai pada ikan asap pembarian bahan pengasap secara bertahap mungkin kadar air yang rendah. Oduor-Odote et al. (2010). juga menyatakan bahwa perbedaan jenis bahan bakar yang digunakan pada proses pengasapan dapat mempengaruhi karateristik, fisik kimia organoleptik dan mikrobiologi ikan asap. Hal ini juga dapat disebabkan oleh waktu serta suhu yang digunakan dalam pengeringan maupun pengasapan berbeda, pengeringan dengan matahari juga dipengaruhi beberapa faktor yaitu kecepatan angin, suhu udara dan kelembaban. Hal ini sesuai dengan pendapat Buckle et al. (2013) faktor-faktor yang mempengaruhi kecepatan pengeringan adalah pengaturan geometris produk sehubungan dengan permukaan alat atau media perantara pemindahan panas, dan sifat-sifat fisik dari lingkungan alat pengeringan seperti suhu, kelembaban dan kecepatan udara. Kadar air ikan pari asap lebih besar dibandingkan dengan produk ikan asap lain, misalnya bandeng asap sebesar 54\%-59\% (pengasapan tradisional cara panas) (Adawyah, 2007), dan lele dumbo asap sebesar 55,02\% (Esminingtyas, 2006). Berdasarkan penelitian Wicaksono et al. (2014), hasil uji kadar air ikan pari asap yang diolah dengan penggunakan suhu $40 \pm 5^{\circ} \mathrm{C}, 60 \pm 5^{\circ} \mathrm{C}$ dan $80 \pm 5^{\circ} \mathrm{C}$ pada tungku $40 \mathrm{~cm}$ yaitu; 60,055\%, 70,17\% dan $70,32 \%$, sedangkan pada tungku $60 \mathrm{~cm}$ yaitu $68,32 \%$; $71,05 \%$ dan $71,58 \%$. Berdasarkan Ikan asap yang diolah dengan menggunakan suhu $70-80^{\circ} \mathrm{C}$ memiliki kadar air yang lebih tinggi dari pada ikan asap yang diolah dengan menggunakan suhu $40^{\circ} \mathrm{C}$ dan $60^{\circ} \mathrm{C}$. Waktu yang dibutuhkan untuk melakukan pengasapan ikan dengan menggunakan suhu $80^{\circ} \mathrm{C}$ lebih cepat daripada menggunakan suhu $40^{\circ} \mathrm{C}$ dan menggunakan suhu $80^{\circ} \mathrm{C}$ lebih cepat daripada menggunakan suhu $40^{\circ} \mathrm{C}$ dan $60 \mathrm{oC}$. Semakin tinggi suhu yang digunakan maka semakin cepat waktu yang dibutuhkan untuk melakukan pengasapan. Menurut Isamu et al. (2012) menyatakan bahwa semakin lama waktu pengasapan, 
akan menyebabkan berkurangnya air ikan asap, sehingga dapat menyebabkan tekstur menjadi lebih keras, sebaliknya bila kadar air tinggi menyebabkan tekstur menjadi lebih lunak. memiliki kadar air lebih dari $60 \%$, sedangkan SNI mensyaratkan kadar air ikan asap maksimal $60 \%$ (BSN, 2013). kurangnya waktu pemanasan dan penirisan. Kadar air dapat mempengaruhi umur simpan ikan asap karena air merupakan salah satu faktor yang diperlukan mikroorganisme untuk perkembangbiakannya. Semakin tinggi kadar air dapat menyebabkan produk semakin mudah rusak oleh mikroorganisme (Agus et al., 2014). Berdasarkan hasil uji proksimat pada penelitian ini menunjukkan bahwa kadar air ikan asap yang dihasilkan sudah sesuai dengan SNI No. 2725:2013 tentang persyaratan mutu ikan asap. Ikan asap yang dihasilkan lama waktu pengasapan yang relatif pendek dan suhu pengasapan yang fluktuatif serta karena tekanan yang terjadi di dalam alat pengasapan dimana asap hasil pembakaran tempurung kelapa sulit keluar dari alat pengasapan sehingga penekan kadar air pada produk pari asap mengalami proses penguapan air tidak stabil dan menyebabkan nilai kadar air masih tinggi. Menurut Winarno et al. (1997), terjadinya penurunan kadar air akibat penguapan dari produk karena pengaruh suhu udara dan kelembaban lingkungan sekitar.

\section{Kadar Abu}

Hasil analisis uji proksimat tembang asap diperoleh nilai kadar abu tertinggi yaitu pada perlakuan gabungan bahan pengasap tongkol jagung dan sabut kelapa (P3) yaitu sebesar $8,48 \%$ dan nilai terendah yakni pada perlakuan pengunaan bahan pengasap tongkol jagung (P2) yaitu sebesar $7,31 \%$. Tingginya kadar abu perlakuan P3 diduga disebabkan bahan pengasap yang di bakar bersamaan banyaknya asap yang dihasilkan. banyaknya penambahan bahan pengasap Menurut Toldra (2008). menjelaskan bahwa pirolisis lignin menghasilkan fenol, sedangkan pirolisis selulosa menghasilkan senyawa asam asetat, senyawa fenol, dan asam asetat adalah senyawa karbonil, senyawa-senyawa tersebut mempunyai sifat fungsional. bahan pengasap, suhu serta jenis ikan yang digunakan sehingga mengakibatkan meningkatnya kadar abu bahan. Kadar abu ikan tembang asap lebih besar dibandingkan dengan hasil penelitian pada beberapa jenis ikan asap yang lain menunjukkan kadar abu ikan bandeng asap sebesar $2,55 \%$ (pengasapan tradisional cara panas), sidat asap sebesar 0,6\%-2,3\% (pengasapan diatas tungku) (Adawyah, 2007), namun lebih kecil bila dibandingkan dengan kadar abu lele dumbo asap sebesar $55,02 \%$ (Esminingtyas, 2006). Hal ini sesuai dengan pendapat Sudarmadji et al. (2007), yang menyatakan bahwa kadar abu tergantung pada jenis bahan, metode penentuan kadar abu, waktu dan suhu yang digunakan saat pengeringan, jika bahan yang diolah melalui proses pengeringan maka lama waktu dan semakin tinggi suhu pengeringan akan meningkatkan kadar abu karena air yang keluar dari dalam bahan semakin besar. Mineral bersifat mantap dan tidak rusak karena pengolahan, namun pengolahan dapat menyebabkan penyusutan mineral maksimal sebesar $3 \%$ pada bahan pangan (Harris dan Karmas, 1989).

\section{Kadar Protein}

Hasil analisis uji proksimat tembang asap diperoleh nilai kadar protein ikan tembang asap diperoleh nilai tertinggi yaitu pada. perlakuan menggunakan bahan pengasap sabut kelapa (P1) yaitu sebesar $46,64 \%$ dan nilai terendah yaitu pada perlakuan penggunanaan bahan pengasap sabut kelapa dan tongkol jagung (P2) yaitu sebesar 44,92\%. Diduga dikarnakan banyaknya asap dan komponen senyawa yang terdapat dalam senyawa bahan pengasap sabut kelapa. Rendahnya kadar protein perlakuan P2 dan P3 disebabkan oleh adanya proses pengolahan terutama penggunakan suhu, pengolahan dilakukan dengan metode penggunaan bahan pengasap tempurung kelapa menggunakan suhu $60^{\circ} \mathrm{C}-80^{\circ} \mathrm{C}$ selama 3 jam.Dibandingkan dalam penelitian lainya kadar protein pada mussel (Mytilus galloprovincialis) yang dilakukan pengasapan mengalami penurunan dari 17,3\% menjadi $16,5 \%(\mathrm{bb})$ (Gulgun et al., 2008), udang rebus (Penaeus semisulcatus) dari $83,81 \%$ menjadi $77,42 \%$ (bk) (Oluwaniyi dan Dosumu, 2009). Berdasarkan penelitian hasil uji kadar protein ikan pari asap yang diolah dengan menggunakan suhu $40 \pm 5^{\circ} \mathrm{C}, 60 \pm 5^{\circ} \mathrm{C}$, 
$80 \pm 5^{\circ} \mathrm{C}$ pada tungku $40 \mathrm{~cm}$ yaitu $29,175 \% ; 28,765 \%$ dan $28,325 \%$. Hasil uji kadar protein pada tungku 60 cm yaitu $29,105 \% ; 28,69 \%$ dan $27,85 \%$. Perbedaan tinggi tungku $40 \mathrm{~cm}$ dengan tungku $60 \mathrm{~cm}$ tidak memberikan pengaruh yang nyata $(P>0,05)$ terhadap kadar protein ikan pari asap, sedangkan perbedaan suhu memberikan pengaruh yang nyata $(P<0,05)$ terhadap kadar protein ikan pari asap. Pengasapan yang dilakukan dengan menggunakan suhu $40 \pm 5^{\circ} \mathrm{C}$ membutuhkan waktu yang lebih lama dari pada menggunakan suhu $80 \pm 5^{\circ} \mathrm{C}$ (Wicaksono et al. 2014). Menurut Isamu et al. (2012), menyatakan bahwa semakin lama waktu pengasapan dan makin banyak jumlah bahan pengasap yang digunakan akan meningkatkan suhu ruang pengasapan, hal ini berpengaruh pada pengurangan kadar air produk akibat panas yang ditimbulkan.

\section{Kadar Lemak}

Hasil analisis uji proksimat tembang asap diperoleh nilai kadar lemak ikan tembang asap diperoleh nilai tertinggi yaitu penggunaan bahan pengasap tengkol jagung (P2) dengan nilai 16,02 \% tingginya kadar lemak pada perlakuan (P2) disebabkan oleh sumber asap yang menghasilkan ikan asap sehingga oksidasi oksidasi lemak tidak terjadi tersebut, sesuai dengan Adawyah (2007) Menyatakan bahwa asap yang dihasilkan dari sumber asap dapat menghambat oksidasi lemak. dan nilai terendah yakni pada perlakuan bahan pengasap sabut kelapa (P1) yaitu sebesar 9,97\%. Rendahnya kandungan kadar lemak pada perlakuan P1 disebabkan oleh bahan pengasap yang diduga asap yang dihasilkan sedikit, (Effendi, 2012). Perbedaan jenis bahan bakar menyebabkan berbeda kadar lemak. Semakin tinggi suhu dan lama pengasapan, menyebabkan penurunan nilai kadar lemak. Mardiana et al. (2014) Menyatakan bahwa asap panas mengakibatkan lemak pada daging ikan akan meleleh keluar dan melapisi permukaan ikan. Pemanasan akan mempercepat gerakan-gerakan molekul lemak, sehingga jarak antara molekul lemak menjadi besar dan akan mempermudah proses pengeluaran lemak (Winarno, 2004).

\section{KESIMPULAN}

Berdasarkan hasil penelitian dan pembahasan, maka dapat disimpulkan sebagai berikut :

1. Terdapat pengaruh dengan penggunaan sabut kelapa dan tongkol jagung terhadap komposisi kimia pada tembang asap. Kandungan kadar air tertinggi perlakuan (P3) 8,75\%, kadar abu tertinggi perlakuan (P3) 10,45\%, kadar protein tertinggi perlakuan (P2) 49,43\% dan kandungan lemak tertinggi pada perlakuan P2 16,30\%.

2. Terdapat pengaruh nyata dengan penggunaan sabut kelapa dan tongkol jagung terhadap nilai sensori Aroma dengan memiliki nilai (P1) 5,83 (P2) 6,15, dan (P3) 6,38

\section{DAFTAR PUSTAKA}

Adawyah, R. 2007. Pengolahan dan Pengawetan Ikan. Bumi Aksara. Jakarta. 160hlm.

Ahmad, Rasyid, 2013. Pembuatan bietanol dari limbah tongkol jagung dengan fariasi konsentrasi asam klorida dan waktu fermentasi.Jurusan Teknik KimiaFakultas Teknik Universitas Sriwijaya.

Afrianto, E. .,dan Liviawaty. 1989. Pengawetan dan Pengolahan Ikan. Yogyakarta : Penerbit Kanisius.
Agus, T. S. W., Swastawati, F. dan Anggo, A. P. 2014. Kulaitas Ikan Pari (Dasyatis sp.) yang Diolah dengan Ketinggian Tungku dan Suhu yang Berbeda. Jurnal Pengolahan dan Bioteknologi Hasil Perikanan, 3(1): 147-156.

Buckle, K. A., R. A. Edwards, G. H. Fleet dan M. Wooton. 2013. IImu Pangan. Terjemahan: $\mathrm{H}$. Purnomo dan Adiono. Universitas Indonesia Press, Jakarta. Hal. 153-156.

Cardinal, M., Cornet J. Serot T. dan Baron R. 2006. 
Effects of the smoking process on odour characteristics of smoked herring (Clupea harengus) and relationships with phenolic compound content. Food Chemistry. 96(1):137-146.

Departemen Pertanian, 2007. Data Produksi Jagung Nasional, www.deptan.go.id.

Djaafar, T. F. 2007. Telur Asin Omega-3 Tinggi. Warta Penelitian dan Pengembangan Pertanian. 29(4) : 4-5. http: www.pustaka-deptan.go.id. 01.54 am. 27/01/2010.

Dwipongo, A. 1982. Beberapa Aspek Biologi Ikan Lemuru, Sardinella Spp. prosiding Seminar Perikanan Lemuru. Buku II. Pusat Penelitian Dan Pengembangan Perikanan Badan Penelitian Dan Pengembangan Pertanian Jakarta.

Effendi, S. 2012 Teknologi Pengolahan Pangan Dan Pengawetan Pangan. Bandung (ID): Alfabeta.

Esminingtyas, R. 2006. Perubahan Mutu Ikan Lele Dumbo (Clarias gariepinus)Asap Selama Penyimpanan. Fakultas Perikanan dan IImu Kelautan. IPB: Bogor.

Guillen, M., dan Errecalde, M. 2002. Volatile components of raw and smoked black bream (Brama raii) and rainbow trout (Onchorhynchus mykiss) studied by means of solid phase microextraction and gas chromatography/mass spectrometri. J Sci Food Agric. 82:945-952.

Gulgun, F. Huseyin G., dan Hanife K. 2008. Determination of the amino acid and chemical composition of canned smoked mussels (Mytilus galloprovincialis, L). Turkey Journal Veteriner Animalia Science. 32(1): 1-5.

Harris, R. S. dan E. Karmas. 1989. Evaluasi Gizi pada Pengolahan Bahan Pangan. Penerjemah: S. Achmadi. ITB - Press, Bandung.

Huda N.,Dewi RS, Ahmad R. 2010. Proximate, color and amino acid profile of Indonesian traditional smoked catfish. Journal of Fisheries and Aquatic Sciences. 5(2): 106-112.

Isamu, K. T., H. Purnomo, dan S. S. Yuwono. 2012. Karakteristik Fisik, Kimia, dan Organoleptik Ikan Cakalang (Katsuwonus pelamis) Asap di Kendari. Jurnal Teknologi. Vol.13 No 2. HIm 105-110.

Jonsdotiir, R., Olafsdottir. G dan Chanie. E 2008. Volatile compounds suitable for rapid detection as quality indicators of cold smoked salmon (Salmor Salar) Food Chem , 109:184185.

KKP. Kementrian Kelautan dan Perikanan. 2019. Produktivitas Perikanan Indonesia Jakarta (ID) Kementrian Kelautan dan Perikanan.

Lempang, M. Syafii W., dan Pari G. 2011. Struktur komponen arang aktif tempurung kemiri. Jurnal Penelitian Hasil Hutan. 29 (3): 278-294.

Lomempuoow, I., Paendong, J., dan Surianto, E 2012. Potensi Antioksidan DAN Fenolik dari Ekstrak Etanol Tongkol Jagung (Zea mays $L$ ). Chem. Prog. Hal 5:49-56.

Mardiana, N., Waluyo, S.,dan Ali, M. 2014. Analisis kualitas ikan sembilang (Paraplotosus albilabris) asap di kelompok pengolahan ikan "mina mulya" kecamatan pasir sakti lampung timur. Jurnal teknik pertanianlampung. Vol. 3. No. 3 : 283-290.

Martinez, O. Salmeron J.,Guillen MD dan Casas C. 2007. Sensorial and physicochemical characteristics of salmon (Salmo salar) treated by different smoking proces during storage. Food Science and TechnologyInternational. 13(6): 477-484

Mutmainnah, 2012. Judul Pemanfaatan Limbah Tongkol Jagung (Ze Mays) Sebagai Arang Aktif Dalam Kadar Aminiah, Nitrit Dan Nitrat Pada Limbah Cair Industri Tahu Mengunakan Teknik Celup.Jurnal Volume13 Nomor 2 Mei 1016 Kimia FMIPA Unmul.

Moeljanto. 1992. Pengawetan dan Pengolahan Hasil Perikanan. Penebar Swadaya. Jakarta.

Nuraini, F. dan O Nawansih.2006 uji sensori.buku ajar.lampung: universitas lampung. $121 \mathrm{hlm}$.

Nontji, A. 1993. Studi Lipid Ikan Tembang (Sardinella Fimbriata). Laut Nusantara PT Djambatan Jakarta.

Oduor-Odote, P. M.,Obiero. M dan Odoli C. 2010 Organoleptic effect of using different plant materials on smoking of marine and fres water catfish. African Jounal And Freshwater Catfish. African Journal of Food Agrculture Nutrition and Development. 10(6):2658-2677.

Oluwaniyi, O. dan Dosumu. O. 2009. Preliminary studies on the effect of processing methods on the quality of three commonly consumed marine fishes in Nigeria. Journal Bio chemystri 21(1): 1-7.

Palungkung, 1992. Tanaman kelapa. penebar swadaya,Jakarta. 
Prananta, J. 2004. Pemanfaatan Sabut dan Tempurung Kelapa serta Cangkang Sawit Untuk Pembuatan Asap Cair Sebagai Pengawet makanan Alami. FMIPA.Universitas Malikussaleh. [Skripsi].

Pino, G. H., Mesquita, L. M. S., Torem, M. L., and Pinto, G. A. 2005.Biosorption of Cadmium by Green Coconut Sheel Powder, Metallurgy and Material, 225, Gavea 22453-900.Rio de Jeneiro-RJ, Brazil.

Richana, N; Lestina, P; Irawadi, T. T. Karakterisasi Lignoselulosa: Xylan dariLimbah Tanaman Pangan dan Pemanfaatannya untuk Pertumbuhan Bakteri RXA III-5 penghasil xilanase. J. Penelitian Pertanian. 2004, 23, 171-176.

Refilda dan Indrawati. 2008. Pembuatan Asap Cair dari Limbah Kayu Suren (Toona sureni), Sabut Kelapa dan Tempurung Kelapa (Cocos nucifera Linn). Jurnal Ris Kim. 1(2) : 187-191.

Saleh., Edy Surianto., dan Adithyah 2012. Aktivitas Dari Ekstrak Tongkol Jagung (Zea Mays L). Program Studi Kimia, FMIPA UNSTRAT, MANADO, 95115.

Sutoro, Y., Sulaeman, dan Iskandar.(1988). Pusat Penelitian dan Pengembangan Tanaman Pangan. Bogor. Badan Penelitian dan Pengembangan Pertanian.

Suratinojo, A. 1988. Pengaruh Enzim Bromelin dan Lama Pemeraman Terhadap Perubahan Protein Daging Ikan Temmbang (Sardinella Fimbriata) UNSRAT Manado.

Sudarmaji, S., B. Hariyono., dan Suhardi. 2007.
Analisa Bahan Makanan dan Pertanian. Liberty. Yogyakarta.

Setyaningrum, A. 2008. Total Antosianin Ekstrak Buah Salam dan Korelasinyan dengan Kapasitas Anti Peroksidasi pada Sistem linoelat. Agrointek.

Sigurgiladottir, S. 2010 Effect of different salting and smoking processees on the microstructure, the texture and yield of atlantic salmon (salmo salar) fillets. Food Research International. 33:847-855.

Toldra, F., 2008. Innovation for healthier processed meats. International Conference on Food Innovation - Foodinnova 2010, Valencia (Spain), 25-29 October 2008.

Widodo, J. dan Suadi. 2006. Pengelolaan Sumberdaya Perikanan Laut. Gajah Mada University Press, Yogyakarta, $252 \mathrm{hlm}$.

Wibowo, S. 2017. Industri Pengasapan Ikan. Jakarta (ID): PT Penebar Swadaya.

Wicaksono, A. T., Fransthea Swastawati dan Aprl Dwi Angga. 2014. Kualitas Ikan Pari (Dasyatis sp) Asap Yang Diolah Dengan Ketinggian Tungku Dan Suhu Yang Berbeda. Fakultas Perikanan dan IImu Kelautan Universitas Dipenogoro Semarang. Hal 147-156.

Winarno, F.G.1997. Kimia Pangan Dan Gizi. Jakarta: Gramedia Pustaka Utama

Winarno, F .G. 2004. GMP: Cara Pengolahan Pangan yang Baik, cetakan ke2. Bogor: M-BRIO Press. 